\title{
Abandoned, lost or otherwise discarded fishing gears in rocky reefs of Southern Brazil
}

\author{
Johnatas Adelir-Alves ${ }^{1 *}$, Gecely Rodrigues Alves Rocha ${ }^{1}$, Thiago Felipe Souza ${ }^{2}$, Pedro Carlos \\ Pinheiro $^{2}$, Kátia de Meirelles Felizola Freire ${ }^{3}$
}

\author{
${ }^{1}$ Programa de Pós-Graduação em Sistemas Aquáticos Tropicais, Universidade Estadual de Santa Cruz. \\ (Rodovia Ilhéus-Itabuna, 45662-900, Ilhéus, BA, Brasil). \\ ${ }^{2}$ Universidade da Região de Joinville. \\ (Rodovia Duque de Caxias, 89240-000, São Francisco do Sul, SC, Brasil. \\ ${ }_{3}^{3}$ Laboratório de Ecologia Pesqueira, Departamento de Engenharia de Pesca e Aquicultura, Universidade Federal de Sergipe \\ (Rua Mal. Rondon S/N, Jardim Rosa Elze, 49100-000, São Cristóvão, SE, Brasil).
}

*Corresponding author: johnatas_alves@yahoo.com

\section{INTRODUCTION}

The intense exploitation of fishing resources has led the activity into a global crisis. However, fishing effort continues to increase despite the collapse of some of the main fish stocks (FAO, 2014). This increasing effort produces both direct and indirect impact on marine ecosystems (PAULY et al., 2002). Marine debris resulting from abandoned, lost or otherwise discarded fishing gear (ALDFG) (LAIST, 1995; MACFADYEN et al., 2009) is one type of indirect impact, responsible for harming marine fauna and for causing economic loss (DAYTON et al., 1995).

ALDFG captures target and non-target fish species by a phenomenon known as 'ghost fishing', which means that the fishing gear continues to catch fish even though fishers are no longer controlling it (SMOLOWITZ, 1978). The term is associated with mortality and injuries inflicted on vertebrates and invertebrates caught by ALDFG (BREEN, 1987; BARREIROS; RAYKOV, 2014).

At least one-third of the Brazilian coast consists of reef environments, with coral reefs concentrated on the northern/ northeastern coast and rocky reefs on the southeastern/ southern coast. These ecosystems are highly diverse, rich in natural resources and of great ecological, economic and social importance, with immense potential for hosting endemic species (FERREIRA et al., 2001; ROCHA, 2003).

There are few studies on the impact of ghost fishing in Brazil, many of them reporting the existence of marine debris and fishing gear found in coastal areas (MACHADO; FILLMANN, 2010; MASCARENHAS et al., 2008; POSSATTO et al., 2011; VIEIRA et al., 2011; DANTAS et al., 2012). Ghost fishing was reported for the first time in Brazil - on the coast of the state of Santa
Catarina - by CHAVES and ROBERT (2009). There is, however, no direct measurement of marine fauna mortality caused by ghost fishing.

The state of Santa Catarina is part of the Brazilian southern region where rocky reefs are dominant. In view of the magnitude of fishing in this state and the vulnerability of reef environments, the objective of this study was to analyze the occurrence and causes of ghost fishing on rocky reefs. Santa Catarina has a coastline approximately 531 $\mathrm{km}$ long and is included in the Atlantic Biogeographical Province (FLOETER; GASPARINI, 2000) and harbors a great variety of environments including rocky reefs (HOSTIM-SILVA et al., 2006).

A total of 84 surveys were carried out around 28 reef sites, between $26^{\circ}$ and $29^{\circ} \mathrm{S}$ (Figure 1) in the search for ALDFG, from November 2011 to December 2012. Surveys were conducted using scuba diving at depths of one to $25 \mathrm{~m}$, with an average underwater duration of $30 \mathrm{~min}$.

Quantitative and qualitative data of ALDFG and entangled species (entanglement only in nets) observed were recorded using plastic board and pencil, photos, and videos. Samples (parts) of gillnets were obtained to measure the mesh size (distance between opposing knots) using a digital caliper (precision of $0.1 \mathrm{~mm}$ ) and images were analyzed. The type of fishing gear was described in accordance with FAO (1990) definitions and the species were identified to the lowest possible taxonomic level.

Information on derelict fishing gear was also obtained through interviews with fishers $(\mathrm{N}=51)$, using a semistructured form based on ALBUQUERQUE et al. (2010), which contained questions related to: location, type of fishing gear, target species, causes, season and methods of prevention of ALDFG. Similar data were further obtained from spearfishers $(\mathrm{N}=43)$. 


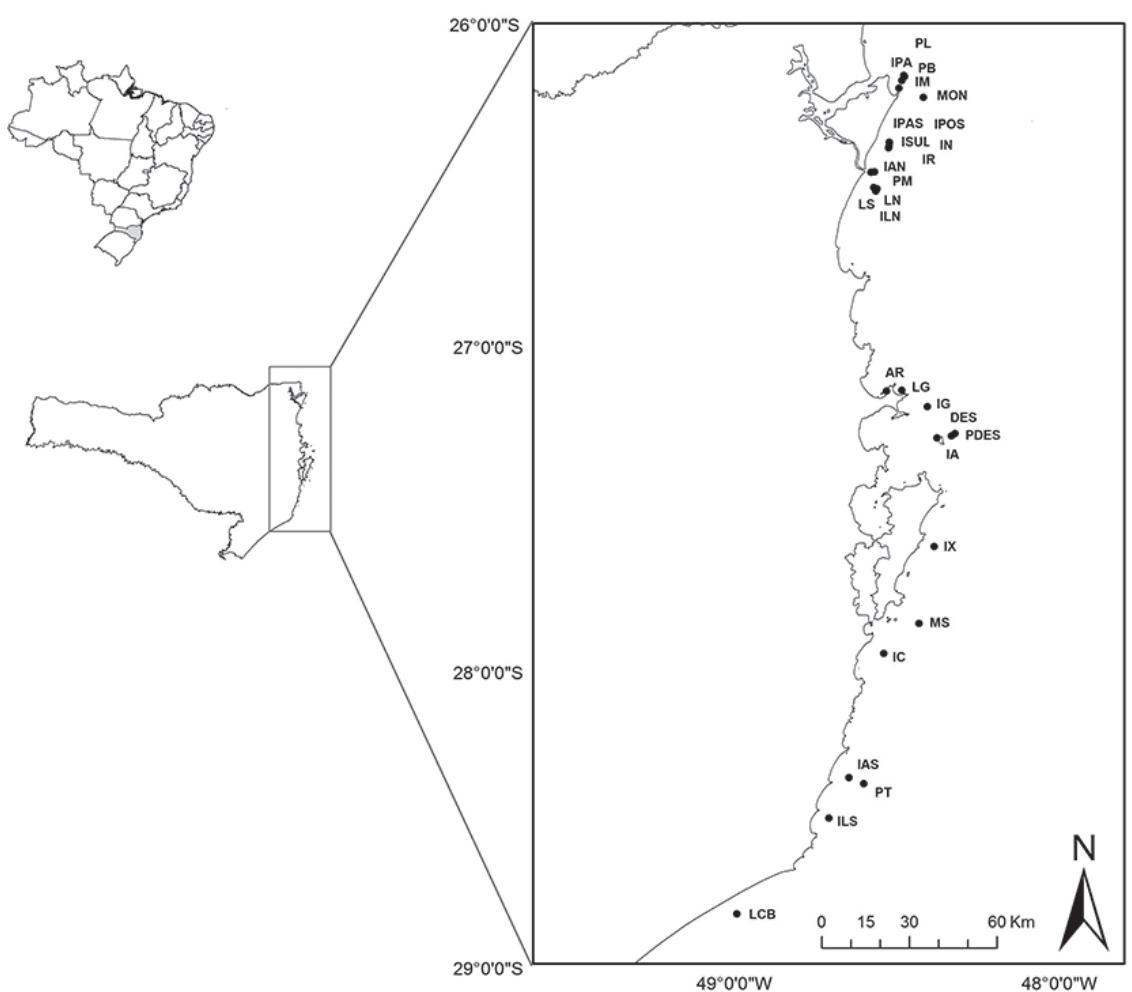

Figure 1. Map showing the survey location along the coast of the state of Santa Catarina, Brazil: Pedra dos Lobos (PL), Pedra da Baleia (PB), Ilha da Paz (IPA), Ilha Mandigituba (IM), Monobóia (MON), Ilha Norte (IN), Ilha do Porto (IPO), Ilha dos Pássaros (IPAS), Ilha Sul (ISUL), Ilha dos Remédios (IR), Ilha das Araras (IAN), Parcel do Meio (PM), Laje Norte (LN), Ilha dos Lobos (ILN), Laje Sul (LS), Araçá (AR), Laje das Garoupas (LG), Ilha Galés (IG), Deserta (DES), Parcel da Deserta (PDES), Ilha do Arvoredo (IA), Ilha do Xavier (IX), Moleques do Sul (MS), Ilhas dos Corais (IC), Ilha das Araras (IAS), Parcel do Tacami (PT), Ilha dos Lobos (ILS), and Laje do Campo Bom (LCB). Map prepared by Diogo A. Moreira.

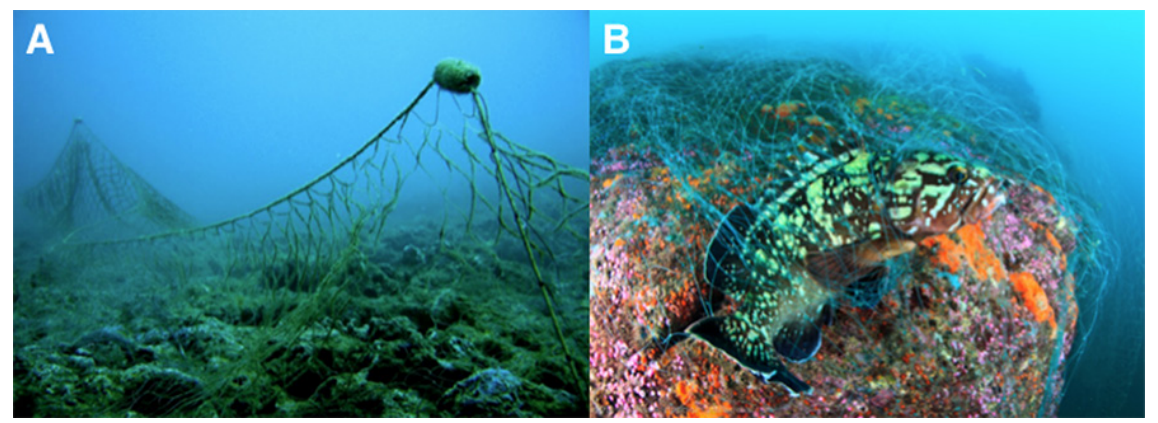

Figure 2. Gillnets, the most common ALDFG found on rocky reefs off the state Santa Catarina (A) and a specimen of E. marginatus entangled in a gillnet (B). Photos: Áthila A. Bertoncini.

We recorded ALDFG in all areas sampled, including those in which fishing is not allowed, such as the Arvoredo Marine Biological Reserve (a marine protected area - MPA) and a restricted region used to unload oil tankers (a national security area).

Twelve types of ALDFG were identified on the coast of the state of Santa Catarina $(\mathrm{N}=107)$, with gillnets (Figure 2) being the most common of them
(Table 1). These nets had seven mesh sizes measured between opposing knots: $90 \mathrm{~mm}(35 \%), 80 \mathrm{~mm}(25 \%)$, $100 \mathrm{~mm}(12 \%)$, and $40,110,120$ and $140 \mathrm{~mm}(\leq 10 \%$ each).

Thirty-two individuals of 12 species were recorded, eight of which were Teleostei and four Crustacea, all found in gillnets (Table 2). The dusky grouper (Epinephelus marginatus) was the most common species found in 
derelict gillnets (Figure 2), followed by crustaceans: Menippe nodifrons, Damithrax hispidus, and Cronius ruber.

Fishers report that bottom gillnets were the most easily lost gears, usually during the winter, due to bad weather conditions. According to fishers, there are also other contributing factors during the winter: a greater fishing effort on stocks of mullet (Mugil spp.) and the occurrence of right whale (Eubalaena australis). Fishers provided a list of ways to prevent ALDFG: enforcement of legislation, investment in location and navigation equipment (light buoy, sonar, VHF radio, and GPS), training in the correct use of fishing gear, and knowledge of weather forecasting (Table 3).

Table 1. Abandoned, Lost or otherwise Discarded Fishing Gear found on rocky reefs, total number $(\mathrm{N})$ and relative abundance (\%).

\begin{tabular}{lll}
\hline Fishing gear & $\mathrm{N}$ & $\%$ \\
\hline Gillnet & 49 & 46 \\
Artificial lure & 14 & 13 \\
Anchor & 13 & 12 \\
Twisted polyamide rope & 8 & 7 \\
Hook & 7 & 6 \\
Sinkers & 5 & 5 \\
Polyamide monofilament & 5 & 5 \\
Traps & 2 & 2 \\
Spear & 1 & 1 \\
Trawl net & 1 & 1 \\
Fishing rod & 1 & 1 \\
Longline & 1 & 1 \\
\hline
\end{tabular}

Table 2. Number and relative abundance (\%) of species found in derelict gillnets on rocky reefs.

\begin{tabular}{lccc}
\hline Group & Species & $\mathrm{N}$ & $\%$ \\
\hline Teleostei & Epinephelus marginatus & 7 & 22 \\
Crustacea & Menippe nodifrons & 5 & 16 \\
Crustacea & Damithrax hispidus & 5 & 16 \\
Crustacea & Cronius ruber & 4 & 13 \\
Teleostei & Anisotremus surinamensis & 3 & 9 \\
Teleostei & Abudefduf saxatilis & 2 & 6 \\
Crustacea & Panulirus laevicauda & 1 & 3 \\
Teleostei & Sparisoma axillare & 1 & 3 \\
Teleostei & Chloroscombrus chrysurus & 1 & 3 \\
Teleostei & Holocentrus adscensionis & 1 & 3 \\
Teleostei & Lagocephalus laevigatus & 1 & 3 \\
Teleostei & Porichthys porosissimus & 1 & 3 \\
\hline
\end{tabular}

Lost gillnets were mainly found near marine rocky habitats because, according to fishers, they are deployed close to islands, cliffs and rocky reef areas, targeting reef species such as the dusky grouper (E. marginatus), snowy grouper (Hyporthodus niveatus), comb grouper (Mycteroperca acutirostris), black margate (Anisotremus surinamensis), sheepshead (Archosargus probatocephalus), sea chub (Kyphosus spp.) as well as other transient species, such as snooks (Centropomus spp.), African pompano (Alectis ciliaris), pompanos (Trachinotus spp.), bluefish (Pomatomus saltatrix), serra Spanish mackerel (Scomberomorus brasiliensis), castin leatherjacket (Oligoplites saliens), and Atlantic spadefish (Chaetodipterus faber).

Spearfishers frequently observe ALDFG, especially gillnets, along the coastline of the state of Santa Catarina. Fishes and crustaceans were the entangled groups observed by all the spearfishers interviewed (Table 4). Six fish species were reported by them: dusky grouper (E. marginatus), bluefish ( $P$. saltatrix), blue runner (Caranx crysos), mullets (Mugil spp.), sheepshead (A. probatocephalus) and sea chub (Kyphosus spp.). Three crustaceans were reported: clinging crab (Damithrax hispidus), lump stone crab (Menippe nodifrons) and smoothtail spiny lobster (Panulirus laevicauda). Sea turtles (Cheloniidae) and the magellanic penguin (Spheniscus magellanicus) were also mentioned.

Table 3. Answers provided by fishers associated with certain issues concerning ALDFG ( $\mathrm{N}=51$ fishers). Number of fishers reporting each answer $(\mathrm{N})$ and relative frequency (\%).

\begin{tabular}{lccc}
\hline Issue & Report & N & $\%$ \\
\hline \multirow{2}{*}{ Fishing gear } & Bottom gillnet & 49 & 96 \\
& Surface gillnet & 15 & 29 \\
\hline \multirow{3}{*}{ Season } & Spring & 14 & 27 \\
& Summer & 15 & 29 \\
& Autumn & 30 & 59 \\
& Winter & 41 & 80 \\
\hline \multirow{4}{*}{ Cause } & Sea condition & 51 & 100 \\
& Accidental removal & 28 & 55 \\
& Unskilled fisher & 18 & 35 \\
& Large individual & 15 & 29 \\
& Debris & 12 & 24 \\
& Disappearance & 6 & 12 \\
\hline \multirow{4}{*}{ Prevention } & Enforcement & 39 & 76 \\
& Equipment & 51 & 100 \\
& Training & 49 & 96 \\
& Weather forecast & 41 & 80 \\
\hline
\end{tabular}


Table 4. Answers reported by spearfishers associated with some issues related to ALDFG ( $\mathrm{N}=43$ fishers). Number of fishers reporting each answer $(\mathrm{N})$ and relative frequency $(\%)$.

\begin{tabular}{lccc}
\hline Issue & Reported & $\mathrm{N}$ & $\%$ \\
\hline \multirow{2}{*}{ Types of fishing } & Gillnets & 43 & 100 \\
gear found & Cables & 40 & 93 \\
& Anchors & 38 & 88 \\
\hline \multirow{3}{*}{ Animals found } & Fishes & 43 & 100 \\
in derelict gillnet & Crustaceans & 43 & 100 \\
& Turtles & 3 & 7 \\
& Birds & 1 & 2 \\
\hline
\end{tabular}

This study revealed that ALDFG is widely distributed on the coast of the state of Santa Catarina, mainly near the shore where fishing activities are more intense. ALDFG has been found within fishing exclusion zones, a fact that had already been reported in other Brazilian studies (CASARINI; OBERG, 2007; GODOY et al., 2007).

Anthropic pressure is greater on coastal islands (GODOY et al., 2007) because these are areas much used by tourists and fishers (both recreational and commercial), thereby increasing ALDFG incidence. Ghost fishing is also observed in areas distant from the coast and even in areas where fishing is restricted, such as conservation units. ALDFG has also been observed in oceanic habitats, such as seamounts and atolls in the Atlantic Ocean (SOARES et al., 2011; PHAM et al., 2013), deep sea (BO et al., 2014), Alaska (MASELKO et al., 2013), Antarctica (CAMPOS et al., 2013), and MPAs in the Pacific Ocean (MORISHIGE; MCELWEE, 2012).

Gillnets are one of the most widely used types of fishing gear in the world (HOVGARD; LASSEN, 2000). This is also true among Brazilian artisanal fishers, probably due to the relatively low investment in equipment and human resources required when compared to other fishing practices. The Brazilian fishing legislation imposes rules for the use of gillnets (BRASIL, Ministério da Pesca e Aquicultura/Ministério do Meio Ambiente, 2012), but fishing laws are not respected (KOTAS et al., 2005) and illegal fishing is one of the possible causes of ALDFG.

The abandonment, loss or discarding of fishing gear on rocky reefs occurs regardless of the type of fishers (commercial or recreational) or fishing methods, and has an impact on vulnerable species (e.g., sharks) and species with high market value such as groupers and lobsters. It is worth pointing out that, although the numbers observed are relatively low, they represent specific cases. The mortality caused is, in fact, much higher due to the great durability of this gear.

Various studies have reported the incidence of the capture, injury, and mortality of marine megafauna caused by ALDFG (GODLEY et al., 1998; GOOD et al., 2009; ALLEN et al., 2012; HONG et al., 2013). ALDFG is considered to be non-selective, thereby posing a risk to marine organisms of all sizes (CHAVES; ROBERT, 2009), as well as to sessile species such as corals (CHIAPPONE et al., 2005; BO et al., 2014). Fish and crustaceans are amongst the groups most affected by ghost fishing (ERZINI et al., 1997).

The dusky grouper (E. marginatus) is an important marine fish resource for the state of Santa Catarina (MACHADO et al., 2003). It should be noted that E. marginatus is currently listed under the category "vulnerable" in Brazil (BRASIL, Ministério do Meio Ambiente, 2014) and classified as "endangered" according to the International List of Endangered Species by the International Union for the Conservation of Nature (CORNISH; HARMELI-VIVIEN, 2004). Spearfishers report frequent observation of this species in derelict gear (gillnets), corroborated by our survey, thereby providing evidence of cumulative losses for the fishing sector (GILARDI et al., 2010) and for the entire ecosystem as this is one of the main predators (SALE, 1991).

Even though no turtles, birds or marine mammals were observed in ALDFG during this study, spearfishers reported incidences of capture for the first two groups. IUCN classified the magellanic penguin as "near to being classified as threatened" (MÄDER; SERAFINI, 2011) and sea turtles occurring along the Brazilian coast are classified as "endangered" or "critically endangered" (MACHADO et al., 2008). The issue of ALDFG thus deserves greater attention than it currently receives in Brazil.

The occurrence of ALDFG usually happens during the winter, probably due to the adverse weather conditions associated with the predominance of southwesterly winds and cold fronts (Frontal Systems) coming from the south (ARAÚJO et al., 2006). The influence of strong winds has also been reported by fishers in Brazil (ALARCON et al., 2009) and other countries (MATTHEWS; GLAZER, 2010).

According to the fishers, there are also other contributing factors in the state of Santa Catarina during that period of the year. A greater fishing effort by commercial and recreational fisheries targeting stocks of species such as mullet (Mugil spp.), bluefish (Pomatomus 
saltatrix), and the whitemouth croaker (Micropogonias furnieri) (SUNYÉ, 2006) leading occasionally to the accidental entanglement of baleen whales (PONTALTI; DANIELSKI, 2011). Further, reports from some areas of the world, have shown that these interactions can result in the mortality or serious injury of marine mammals (READ et al., 2006).

Accidental removal by other vessels, unskilled handling of fishing gear by recreational fishers, entanglement of large fish, presence of plant debris (such as tree trunks and branches), and disappearance of fishing gear have also been reported to be factors leading to ALDFG in Santa Catarina. Accidents, rough seas, driftwood or debris, and large fish were other causes cited in other Brazilian states (CHAVES; ROBERT, 2009), as well as in other countries (LAIST, 1995). The main factors leading to ALDFG include adverse weather, damage to gear, collision with other vessels, entanglement in reefs, shipwrecks or other fishing gear, operational problems (including human error), vandalism, and unregulated or illegal fishing (LAIST, 1995; BAIRD, 2006).

The fishers who participated in this study have suggested actions for tackling the effects of ALDFG. In some European countries, studies undertaken with fishers to prevent fishing gear being lost, abandoned or discarded have been proven to be efficient (PAWSON, 2003; MACFADYEN et al., 2009).

Efforts have been made to reduce the impact of ghost fishing through: techniques designed to find the lost gear (MCELWEE et al., 2011; MORISHIGE; MCELWEE, 2012), manual removal by divers or vessels (LARGE et al., 2005), incorporation of biodegradable products into fishing gear (BILKOVIC et al., 2012), technological support for fishers (CHAVES; ROBERT, 2009), and enforcement of laws that control the hidden impact of ALDFG.

As mentioned above, ALDFG is not a problem restricted to Brazil. Thus, studies and actions for tackling the effects of ghost fishing have been carried out in many countries (VAN DER LAST, 2011; CHEN; LIU, 2013). The cost-effectiveness of these methods of control is positive (BUTLER et al., 2013), mainly for the fishing sector (ANTONELIS et al., 2011), but also for local and global marine biodiversity (GILARDI et al., 2010). About $10 \%$ of fishing gear is lost during fishing operations and thus ALDFG is unavoidable wherever fishing takes place (MACFADYEN et al., 2009).

Fishing activities provide many benefits for society, such as food, employment, business, and leisure. It is crucial that these benefits continue to be available in the future. Any policy designed to protect its sustainable use should incorporate knowledge regarding the impact that fishing has on fishery resources and its environmental support system.

Fishing management in the state of Santa Catarina reflects the problems of the national system. The fishing sector neither recognize the existence of the ghost fishing problem nor adequately recognize its importance.

This indirect impact of fishing activity is rarely included in Brazilian studies, such as those on fisheries management or marine conservation, mainly due to the absence of data. Thus, the results presented here can be used as a basis for some areas of knowledge, provide the first data on the impact of ghost fishing on Brazilian rocky reefs.

\section{ACKNOWLEDGMENTS}

We would like to thank the scientific diving team of the COMAR Institute for their collaboration in the fieldwork; the State University of Santa Cruz; Meros do Brasil and Pró-Arribada projects; the Brazilian Center for Research and Management of Fishery Resources on the Southeastern and Southern Coast (CEPSUL/IBAMA) for their assistance with logistics and equipment; the Chico Mendes Institute for Biodiversity Conservation - ICMBio for the license (SISBIO 31065-1); and the Brazilian Coordination of Improvement for Higher Education Personal (CAPES) for a scholarship provided for the first author.

\section{REFERENCES}

ALARCON, D. T.; DÂMASO, R. C. S. C.; SCHIAVETTI, A. Abordagem etnoecológica da pesca e captura de espécies não-alvo em Itacaré, Bahia (Brasil). Bol. Inst. Pesca, v. 35, n. 4, p. 675-686, 2009

ALBUQUERQUE, U. P.; LUCENA, R. F. P.; LINS NETO, E. M. F. Seleção dos participantes da pesquisa. In: ALBUQUERQUE, U. P.; LUCENA, R. F. P.; CUNHA, L. F. C. (Orgs.). Métodos e técnicas na pesquisa etnoecológica e etnobiológica. Recife: NUPEEA, 2010. $558 \mathrm{p}$.

ALLEN, R.; JARVIS, D.; SAYER, S.; MILLS, C. Entanglement of grey seals Halichoerus grypus at a haul out site in Cornwall, UK. Mar. Pollut. Bull., v. 64, n. 12, p. 2815-2819, 2012.

ANTONELIS, K.; HUPPERT, D.; VELASQUEZ, D.; JUNE, J. Dungeness Crab mortality due to lost traps and a cost-benefit analysis of trap removal in Washington State waters of the Salish Sea. N. Am. J. Fish. Manage., v. 31, n. 5, p. 880-893, 2011.

ARAÚJO, S. A.; HAYMUSSI, H.; REIS, F. H.; SILVA, F. E. Caracterização climatológica do município de penha, SC. In: BRANCO, J. O.; MARENZI, A. W. C. (Orgs.). Bases ecológicas para um desenvolvimento sustentável: estudos de caso em Penha, SC. Itajaí: UNIVALI, 2006. p. 11-28. 
BAIRD, R. J. Aspects of illegal, unreported and unregulated fishing the Southern Ocean. Berlin: Springer, 2006. 286 p.

BARREIROS, J. P.; RAYKOV, V. S. Lethal lesions and amputation caused by plastic debris and fishing gear on the loggerhead turtle Caretta caretta (Linnaeus, 1758). Three case reports from Terceira Island, Azores (NE Atlantic). Mar. Pollut. Bull., v. 86, n. 1-2, p. 518-522, 2014.

BILKOVIC, D. M.; HAVENS, K. J.; STANHOPE, D. M.; ANGSTADT, K. T. Use of fully biodegradable panels to reduce derelict pot threats to marine fauna. Conserv. Biol., v. 26, n. 6, p. 957-966, 2012.

BO, M.; BAVA, S.; CANESE, S.; ANGIOLILlO, M.; CATTANEO-VIETTI, R.; BAVESTRELLO, G. Fishing impact on deep Mediterranean rocky habitats as revealed by ROV investigation. Biol. Conserv., v. 171, p. 167-176, 2014.

BREEN, P. A. Mortality of dungeness crabs caught by lost traps in the Fraser River Estuary, British Columbia. N. Am. J. Fish. Manage., v. 7, n. 3, p. 429-435, 1987.

BRASIL. Ministério do Meio Ambiente. Portaria no 445, de 17 de dezembro de 2014. Fauna Aquática. Brasília: Ministério do Meio Ambiente, 2014.

BRASIL. Ministério da Pesca e Aquicultura/Ministério do Meio Ambiente. Instrução Normativa Interministerial Ministério da Pesca e Aquicultura/Ministério do Meio Ambiente $n^{\circ}$ 12, de 22 de agosto de 2012. Brasília: Ministério da Pesca e Aquicultura/Ministério do Meio Ambiente, 2012.

BUTLER, J. R. A.; GUNN, R.; BERRY, H. L.; WAGEY, G. A.; HARDESTY, B. D.; WILCOX, C. A value chain analysis of ghost nets in the Arafura Sea: identifying trans-boundary stakeholders, intervention points and livelihood trade-offs. J. Environ. Manage., v. 123, p. 14-25, 2013.

CAMPOS, L. S.; MONTONE, R. C.; MOURA, R. B.; YONESHIGUE-VALENTIN, Y.; KAWALL, H. G.; CONVEY, P. Anthropogenic impacts on Sub-Antarctic and Antarctic Islands and the adjacent marine environments, Chapter 10. In: VERDE, C.; PRISCO, G. (Eds.). Adaptation and evolution in marine environments, from pole to pole. Berlin: Springer-Verlag, 2013. p. 177-203.

CASARINI, L. M.; OBERG, I. M. F. Áreas marinhas de exclusão a pesca em dutos e plataformas de prospecção de gás na Bacia de Santos. In: GONÇALVES, A.; RODRIGUES, G. M. A. (Orgs.). Direito do petrólelo e gás: aspectos ambientais e internacionais. Santos: Universitária Leopoldianum, 2007. p. 228-249.

CHAVES, P. T.; ROBERT, M. C. Extravios de petrechos e condições para ocorrência de pesca-fantasma no litoral Norte de Santa Catarina e sul do Paraná. Bol. Inst. Pesca, São Paulo, v. 35, n. 3, p. 513-519, 2009.

CHEN, C. L.; LIU, T. K. Fill the gap: developing management strategies to control garbage pollution from fishing vessels. Mar. Policy, v. 40, p. 34-40, 2013.

CHIAPPONE, M.; DIENES, H.; SWANSON, D. W.; MILLER, S. L. Impacts of lost fishing gear on coral reef sessile invertebrates in the Florida Keys National Marine Sanctuary. Biol. Conserv., v. 121, n. 2, p. 221-230, 2005.

CORNISH, A.; HARMELIN-VIVIEN, M. Epinephelus marginatus. (Grouper and Wrasse Specialist Group). The IUCN Red List of Threatened Species. World Wide Web electronic publication. 2004. Available: < http://www. iucnredlist.org > . Accessed: 10 jun. 2014.
DANTAS, D. V.; BARLETTA, M.; COSTA, M. F. The seasonal and spatial patterns of ingestion of polyfilament nylon fragments by estuarine drums (Sciaenidae). Environ. Sci. Pollut. Res. Int., v. 19, n. 2, p. 600-606, 2012.

DAYTON, P. K.; THRUSH, S. F.; AGARDY, M. T.; HOFMAN, R. J. Environmental effects of marine fishing. Aquat. Conserv., v. 5, n. 3, p. 205-232, 1995.

ERZINI, K.; MONTEIRO, C. C.; RIBEIRO, J.; SANTOS, M. N.; GASPAR, M.; MONTEIRO, P.; BORGES, T. C. An experimental study of gillnet and trammel net 'ghost fishing' of the Algarve (southern Portugal). Mar. Ecol-Prog. Ser., v. 158, p. 257-265, 1997.

FAO. Fishing gear classification. Food and Agriculture Organization of the United Nations. Rome: Fisheries Technical Paper, 1990. 92 p.

FAO. The state of world fisheries and aquaculture. Food and Agriculture Organization of the United Nations. Rome, 2014. 223 p.

FERREIRA, C. E. L.; GONÇALVES, J. E. A.; COUTINHO, R. Community structure of fishes and habitat complexity on a tropical rocky shore. Environ. Biol. Fish., v. 61, n. 4, p. 353369, 2001.

FLOETER, S. R.; GASPARINI, J. L. The southwestern Atlantic reef fish fauna: composition and zoogeographic patterns. J. Fish Biol., v. 56, n. 5, p. 1099-1114, 2000.

GILARDI, K. V. K.; CARLSON-BREMER, D.; JUNE, J. A.; ANTONELIS, K.; BROADHURST, G.; COWAN, T. Marine species mortality in derelict fishing nets in Puget Sound, WA and the cost/benefits of derelict net removal. Mar. Pollut. Bull., v. 60, n. 3, p. 376-382, 2010.

GODLEY, B. J.; GAYWOOD, M. J.; LAW, R. J.; MCCARTHY, C. J.; MCKENZIE, C.; PATTERSON, I. A. P.; PENROSE, R. S.; REID, R. J.; ROSS, H. M. Patterns of marine turtle mortality in British waters (1992-1996) with reference to tissue contaminant levels. J. Mar. Biol. Assoc. U.K., v. 78, p. 973-984, 1998.

GODOY, E. A. S.; DAROS, F. A.; GERHARDINGER, L. C.; BERTUOL, P. R. K.; MACHADO, L. F.; ANDRADE, A. B.; HOSTIM-SILVA, M. Projeto Peixes de Costão Rochoso de Santa Catarina: subsídios para conservação. In: PRATES, A. P.; BLANC, D. (Eds.). Áreas protegidas do Brasil: áreas aquáticas protegidas como instrumento de gestão pesqueira. Brasília: Ministério do Meio Ambiente, 2007. p. 89-105.

GOOD, T. P.; JUNE, J. A.; ETNIER, M. A.; BROADHURST, G. Ghosts of the Salish Sea: threats to marine birds in Puget Sound and the Northwest Straits from derelict fishing gear. Mar. Ornithol., v. 37, p. 67-76, 2009.

HONG, S.; LEE, J.; JANG, Y. C.; KIM, Y. J.; KIM, H. J.; HAN, D.; HONG, S. H.; KANG, D.; SHIM, W. J. Impacts of marine debris on wild animals in the coastal area of Korea. Mar. Pollut. Bull., v. 66, n. 1-2, p. 117-124, 2013.

HOSTIM-SILVA, M.; ANDRADE, A. B.; MACHADO, L. F.; GERHARDINGER, L. C.; DAROS, F. A. M.; BARREIROS, J. P.; GODOY, E. A. S. Peixes de costão rochoso de Santa Catarina: Arvoredo. Itajaí: Universidade do Vale do Itajaí, 2006. $135 \mathrm{p}$.

HOVGARD, H.; LASSEN, H. Manual on estimation of selectivity for gillnet and longline gears in abundance surveys. Rome: FAO Fisheries Technical Paper, 2000. 84 p. 
KOTAS, J. E.; PETRERE JR., M.; AZEVEDO, V. G.; SANTOS, S. A pesca de emalhe e de espinhel de superfície na Região Sudeste-Sul do Brasil. Série documentos REVIZEE - Score Sul. São Paulo: Instituto Oceanográfico, 2005. 72 p.

LAIST, D. W. Marine debris entanglement and ghost fishing: a cryptic and significant type of bycatch. In: Proceedings of the Solving Bycatch Workshop, September 25-27, Seattle, 1995. p. $33-40$.

LARGE, P.; REVILL, A.; RANDALL, P.; ARMSTRONG, M.; HOUGHTON, C.; HAREIDE, N. Programme 5: Western Edge Ghost Nets (gillnet retrieval). Fisheries Science Partnership Report., 2005. 22 p.

MACFADYEN, G.; HUNTINGTON, T.; CAPPELL, R. Abandoned, lost or otherwise discarded fishing gear. UNEP Regional Seas Reports and Studies No.185; FAO Fisheries and Aquaculture Technical Paper, No. 523. Rome, UNEP/ FAO, 2009. $115 \mathrm{p}$.

MACHADO, A. A.; FILLMANN, G. Estudo da contaminação por resíduos sólidos na Ilha do Arvoredo, Reserva Biológica Marinha do Arvoredo - SC, Brasil. J. Integr. Coast. Zone Manage., v. 10, n. 3, p. 381-393, 2010.

MACHADO, A. B. M., DRUMMOND, G. M.; PAGLIA, A. P. Livro vermelho da fauna brasileira ameaçada de extinção. Brasília: Ministério do Meio Ambiente, 2008.

MACHADO, L. F.; ANDRADE, A. B.; HOSTIM-SILVA, M.; BARREIROS, J. P. Habitat use by the juvenile dusky grouper Epinephelus marginatus and its relative abundance in Santa Catarina, Brazil. Aqua J. Ichthyol. Aquat. Biol., v. 6, n. 4, p. 133-138, 2003.

MÄDER, A.; SERAFINI, P. Programa Nacional de Monitoramento do Pinguim-de-Magalhães (Spheniscus magellanicus) 2010-2015. Boletim Pinguins no Brasil $\mathrm{n}^{\circ} 1$. Florianópolis: Programa Nacional de Monitoramento do Pinguim-de-Magalhães, 2011. 8 p.

MASCARENHAS, R.; BATISTA, C. P.; MOURA, I. F.; CALDAS, A. R.; COSTA NETO, J. M.; VASCONCELOS, M. Q.; ROSA, S. S.; BARROS, T. V. S. Lixo marinho em área de reprodução de tartarugas marinhas no Estado da Paraíba (Nordeste do Brasil). J. Integr. Coast. Zone Manage., v. 8, n. 2, p. 221-231, 2008.

MASELKO, J.; BISHOP, G.; MURPHY, P. Ghost fishing in the southeast Alaska commercial Dungeness crab fishery. N. Am. J. Fish. Manage., v. 33, n. 2, p. 422-431, 2013.

MATTHEWS, T.; GLAZER, R. Assessing opinions on abandoned, lost, or discarded fishing gear in the Caribbean: a final report. Marathon: Gulf and Caribbean Fisheries Institute, 2010. 17 p.

MCELWEE, K.; DONOHUE, M. J.; COURTNEY, C. A.; MORISHIGE, C.; RIVERA-VICENTE, A. A strategy for detecting derelict fishing gear at sea. Mar. Pollut. Bull., v. 65, n. 1-3, p. 7-15, 2011.
MORISHIGE, C.; MCELWEE, K. At-sea detection of derelict fishing gear in the North Pacific: An overview. Mar. Pollut. Bull., v. 65, n. 1-3, p. 1-6, 2012.

PAULY, D.; CHRISTENSEN, V.; GUÉNETTE, S.; PITCHER, T. J.; SUMAILA, U. R.; WALTERS, C.; WATSON, R.; ZELLER, W. D. Towards sustainability in world fisheries. Nature, v. 418, p. 689-695, 2002.

PAWSON, M. G. The catching capacity of lost static fishing gears: introduction. Fish. Res., v. 64, n. 2-3, p. 101-105, 2003.

PHAM, C. K.; GOMES-PEREIRA, J. N.; ISIDRO, E. J.; SANTOS, R. S.; MORATO, T. Abundance of litter on Condor Seamount (Azores, Portugal, Northeast Atlantic). Deep Sea Res. Part II Top. Stud. Oceanogr., v. 98, n. Part A, p. 204208,2013

PONTALTI, M.; DANIELSKI, M. Registros de enredamentos de baleias-franca, Eubalaena australis (Cetacea, Mysticeti), na temporada reprodutiva de 2010, em Santa Catarina, Brasil. Biotemas, v. 24, n. 2, p. 109-112, 2011.

POSSATTO, F. E.; BARLETTA, M.; COSTA, M. F.; IVAR DO SUL, J. A.; DANTAS, D. V. Plastic debris ingestion by marine catfish: an unexpected fisheries impact. Mar. Pollut. Bull., v. 62, n. 5, p. 1098-1102, 2011.

READ, A. J.; DRINKER, P.; NORTHRIDGE, S. Bycatch of marine mammals in U.S. and global fisheries. Conserv. Biol., v. 20, n. 1 , p. $163-169,2006$

ROCHA, L. A. Patterns of distribution and processes of speciation in Brazilian reef fishes. J. Biogeogr., v. 30, n. 8, p.1161-1171, 2003.

SALE, P. F. The ecology of fishes on coral reefs. London: Academic Press, 1991. 754 p.

SMOLOWITZ, R. J. Trap design and ghost fishing: discussion. Mar. Fish. Rev., v. 40, p. 59-67, 1978.

SOARES, M. O.; PAIVA, C. C.; GODOY, T.; SILVA, M. B. Rocas Atoll (Equatorial South Atlantic): a case of marine debris in remote areas. J. Integr. Coast. Zone Manage., v. 11, n. 1, p. 149-152, 2011.

SUNYÉ, P. S. Diagnóstico da pesca no litoral do Estado de Santa Catarina. In: ISAAC, V. N.; HAIMOVICI, M.; MARTINS, S. A.; ANDRIGUETTO, J. M. (Orgs.). A pesca marinha e estuarina do Brasil no início do século XXI: recursos, tecnologias, aspectos socioeconômicos e institucionais. Belém: UFPA, 2006. p. 141-156.

VAN DER LAST, N. The impacts of ghost fishing in the Dutch North Sea: an introduction of the scale of the phenomenon and proposed management strategies. Final Report. Culemborg: Bureau Waardenburg bv, 2011. 45 p.

VIEIRA, B. P.; DIAS, D.; HANAZAKI, N. Homogeneidade de encalhe de resíduos sólidos em um manguezal da Ilha de Santa Catarina, Brasil. J. Integr. Coast. Zone Manage., v. 11, n. 1, p. 21-30, 2011 
